\title{
Effect of Soil Moisture Management on the Development of Potato mop-top virus-Induced Tuber Necrosis
}

\author{
O. Domfeh and N. C. Gudmestad, Department of Plant Pathology, North Dakota State University, Fargo 58108
}

\begin{abstract}
Domfeh, O., and Gudmestad, N. C. 2016. Effect of soil moisture management on the development of Potato mop-top virus-induced tuber necrosis. Plant Dis. 100:418-423.

Potato mop-top virus (PMTV), transmitted by Spongospora subterranea f. sp. subterranea, the causal agent of powdery scab in potato, has become one of the most important tuber necrosis viruses in the United States. The virus has been confirmed in six major potato-producing states in the United States since its identification in 2003. Currently, no control methods are available for PMTV or its vector. A growth-chamber experiment was conducted to investigate the potential of using moisture regime adjustments to manage tuber necrosis caused by PMTV. Two commercial potato cultivars with varying levels of sensitivity to PMTV, 'Dakota Crisp' and 'Ivory Crisp', were grown in soil obtained from a PMTVinfested field. Over the course of the plant growth cycle, plants of each cultivar were subjected to moisture regimes of wet throughout (WT), wet early/dry late (WEDL), dry early/wet late (DEWL), and dry throughout (DT). Soil moisture levels of 90 and $60 \%$ field capacity were considered wet and dry, respectively, while early and late refer to first and last 50 days after planting, respectively. Results of visual assessment conducted 3 months after storage showed significant differences in root gall formation, powdery scab on tubers, and PMTV tuber necrosis among

moisture regimes. Powdery scab incidence was significantly higher in the WT and DEWL regimes than WEDL and DT regimes. PMTV tuber necrosis incidence did not differ between the WT and DEWL or between DEWL and WEDL moisture regimes. However, PMTV tuber necrosis incidence was significantly higher in WT than under WEDL and DT regimes. The incidence of PMTV tuber necrosis was significantly lower in the DT regime than in the other three moisture regimes. Severity of PMTV tuber necrosis was significantly higher in the WT than the other regimes, which did not differ statistically among themselves. A significant interaction was found between cultivar and moisture regime on root gall formation, with the highest number of galls found on Ivory Crisp grown in the WT moisture regime. A significant correlation was found between powdery scab incidence on tubers and PMTV-induced tuber necrosis incidence. The results of this study provide useful basic information upon which further work can be built for formulating irrigation management schemes that have the potential of reducing the likelihood of powdery scab infection and PMTV-induced tuber necrosis development in potato.
\end{abstract}

Potato mop-top virus (PMTV), classified as the type member of the genus Pomovirus (Pringle 1999; Torrance and Mayo 1997), causes necrotic symptoms in sensitive potato cultivars (Domfeh et al. 2015; Harrison and Jones 1970; Latvala-Kilby et al. 2009; Nielsen and Molgaard 1997; Sandgren et al. 2002; Santala et al. 2010). Symptoms of PMTV include internal rust-colored arcs, rings, and lines (Calvert and Harrison 1966; Harrison and Jones 1970; Kurppa 1989) which are sometimes visible on the tuber surface (Jeffries 1998). PMTV can also induce cracking of tubers and a wide range of foliar symptoms, including yellow blotches or rings, mottling, and stunting in potato plants (Calvert and Harrison 1966; Harrison and Jones 1970; Kurppa 1989).

PMTV is transmitted by the zoospores of the soilborne biotrophic protozoan pathogen Spongospora subterranea f. sp. subterranea (Arif et al. 1995; Jones and Harrison 1969), which also causes powdery scab in potato. Powdery scab is characterized by cankers and scabs on tubers (Hims and Preece 1975) and makes tubers appear unsightly, resulting in extensive economic losses (Wale 2000). In addition, infected root systems may develop galls containing cystosori which can survive in the soil for many years (Andersen et al. 2002; Jones and Harrison 1969, 1972). PMTV resides in the cystosori and can also persist for several years (Calvert 1968; Jones and Harrison 1972), making it very difficult, if not impossible, to eliminate it from an infested field. Field-to-field spread of PMTV occurs through planting infected seed tubers, movement of infested soil and seed tubers, or machinery with adhered viruliferous cystosori (Sandgren et al. 2002).

Corresponding author: N. C. Gudmestad; E-mail: Neil.Gudmestad@ndsu.edu Accepted for publication 10 August 2015.

http://dx.doi.org/10.1094/PDIS-05-15-0590-RE

(c) 2016 The American Phytopathological Society
Cool temperatures and high soil moisture conditions favor $S$. subterranea $\mathrm{f}$. sp. subterranea infection by providing a favorable environment for release and motility of zoospores (Jones and Harrison 1969; Sandgren et al. 2002; Wale 2000). As a result, powdery scab infection is most prevalent in countries with cool, wet climates. In some warmer countries, S. subterranea f. sp. subterranea and PMTV infection have been reported, mainly from cool areas with high altitudes (Montero-Astúa et al. 2008; Salazar and Jones 1975). The upsurge in powdery scab outbreaks in the potato-growing industry in recent years has been linked with use of popular but susceptible cultivars, increased use of irrigation, and the lack of an effective seed tuber inspection scheme (Harrison et al. 1997; Qu et al. 2006; Taylor and Flett 1981; Taylor et al. 1986; Wale 2000). Environmental factors that favor PMTV infection are generally considered to be those required for $S$. subterranea $\mathrm{f}$. sp. subterranea infection in potato. In Scotland, it has been reported that the occurrence of PMTV follows rainfall and, when the annual precipitation falls below $760 \mathrm{~mm}$, there is virtually no PMTV infection (Cooper and Harrison 1973). This is not true in all cases, because in Sweden, PMTV occurs in the eastern part of the potato-growing area where precipitation is below $760 \mathrm{~mm}$ (Sandgren 1995). In another study in Denmark, the incidence of PMTV tuber necrosis was shown to correlate best with precipitation at the period when stolon formation and tuber set occurs and when tubers are infected by $S$. subterranea f. sp. subterranea (Jones 1988).

Conditions that replicate the cool, wet soils reported to favor development of powdery scab occur after irrigation (de Boer et al. 1985), and this may have consequences for PMTV infection. It has been widely reported that the period at and shortly after tuber set is the most susceptible period for $S$. subterranea f. sp. subterranea development (Taylor and Flett 1981; Taylor et al. 1986). Therefore, many authors have suggested that powdery scab incidence and severity can be substantially reduced by delaying irrigation until tuber set or several weeks post tuber set (Adams et al. 1987; Burnett 1991; de Boer et al. 1985; Taylor and Flett 1981). Other reports 
suggest that wet conditions later in the growing season may still result in S. subterranea f. sp. subterranea infection (Adams 1975; Christ and Weidner 1988; Forsund 1971; Hims 1976a,b; Parker 1984).

The effect of different moisture regimes on powdery scab development has been extensively studied in controlled experiments; however, no such studies have been conducted to determine the influence of moisture regimes on PMTV tuber necrosis development. The objective of this study was to investigate how soil moisture regimes affect the development of PMTV-induced tuber necrosis. This was accomplished through a growth chamber experiment using $S$. subterranea f. sp. subterranea- and PMTV-infested field soil.

\section{Materials and Methods}

Determination of soil properties. Soil was obtained from a field in Grand Forks County, ND, known to be infested with PMTV and $S$. subterranea f. sp. subterranea through previous trials (Domfeh et al. 2015). The soil (sandy loam, with $3 \%$ organic matter content) was mixed, air dried for 3 weeks, and sieved to remove large lumps and plant debris thereafter. The field capacity of the soil was determined using two samples weighing $250 \mathrm{~g}$ each (Cassel and Nielsen 1999). The gravimetric water content of the soil was determined by weighing a sample of the soil, followed by oven drying at $105^{\circ} \mathrm{C}$ for $48 \mathrm{~h}$ and reweighing (Reynolds 1970). The gravimetric water content of the air-dried soil was then determined by the equation:

$$
\theta=\frac{(\text { Soil mass }(\text { wet })-\text { Soil mass }(\text { dry }))}{\text { Soil mass }(\text { dry })}
$$

The same quantity of soil $(2,650 \mathrm{~g})$ was used in each pot and the amount of water required to bring this soil to 60 or $90 \%$ field capacity was determined by exploring the relationship between density of water, gravimetric water content, and field capacity.

Growth chamber experiment. The treatments consisted of four moisture regimes implemented over the course of the plant growth cycle. Each treatment was replicated eight times in two potato cultivars arranged in a completely randomized design with one plant per replication. The experiment was performed twice. The moisture regimes were wet early/dry late (WEDL), dry early/wet late (DEWL), wet throughout (WT), and dry throughout (DT). Dry treatments were maintained at $60 \%$ field capacity while wet treatments were kept at $90 \%$ field capacity moisture levels. The WEDL treatment received water at $90 \%$ field capacity up to 50 days postplanting and $60 \%$ field capacity for the remaining 50 days. The DEWL treatment was kept at $60 \%$ field capacity for the first 50 days postplanting and at $90 \%$ field capacity for a further 50 days. The WT and DT treatments were kept at 90 and 60\% field capacity, respectively, throughout the duration of the experiment. 'Ivory Crisp' and 'Dakota Crisp' potato plants, tolerant and sensitive to PMTVinduced tuber necrosis, respectively (Domfeh et al. 2015), were subjected to each moisture regime. Ivory Crisp is very susceptible to tuber scab and moderately susceptible to root galling while Dakota Crisp is moderately resistant to both tuber scab and root gall formation (F. G. Bittara, personal communication).

Potato seed tubers were planted in pots filled with $1,325 \mathrm{~g}$ of soil (half of 2,650 g) and watered with 156 or $253 \mathrm{ml}$ of water (i.e., half of 312 or $505 \mathrm{ml}$ ) predetermined to bring the moisture level to 60 or $90 \%$ field capacity, respectively. Following this, the remaining amount of soil $(1,325 \mathrm{~g})$ was added and watered with the remaining half of water to bring the moisture level to 60 or $90 \%$ field capacity. This was done to ensure that water got to the seed tubers to facilitate germination, which was necessary, particularly, in the case of dry treatments. The potato seed tubers were planted in plastic azalea pots which were $22 \mathrm{~cm}$ wide around the top and $17 \mathrm{~cm}$ deep.

Water was applied twice daily throughout the experiment. During the first 3 weeks, each pot was weighed and the amount of water lost was found by subtracting the current weight from the initial weight (taken at planting). Water was added accordingly to bring the moisture levels to 60 or $90 \%$ field capacity. Subsequently, determination of the amount of water to apply was done with a moisture sensor (HydroSense; Campbell Scientific) because weight measurements were no longer appropriate as the potato seed pieces began to germinate and soil containers gained weight due to increased plant mass. The two probes of the moisture sensor (12 cm long and spaced $3.2 \mathrm{~cm}$ apart) were carefully inserted into at least three different locations in each pot and the average percent volumetric water content was calculated. This reading was subtracted from the initial reading (percent volumetric water content taken at planting) and the amount of water required was calculated through proportions. Throughout the experiment, day and night temperatures were maintained at $16^{\circ} \mathrm{C}(16 \mathrm{~h})$ and $12^{\circ} \mathrm{C}(8 \mathrm{~h})$, respectively. Granules of Osmocote plus 15-9-12 (3 to 4 months), applied at the rate of $5 \mathrm{~g} / \mathrm{pot}$, provided nutrient fertilization.

Root gall evaluation. All plants were carefully removed from soil at the end of the experiment (100 days after planting). Roots were gently shaken and washed under gently running tap water to release attached soil. Galls were evaluated under a magnifying glass. Galls on roots were counted and expressed as number of galls per plant (Hernandez Maldonado et al. 2013).

Postharvest tuber evaluation. After harvest, tubers were cured at a temperature of $10^{\circ} \mathrm{C}$ for 3 weeks and stored at 8 to $10^{\circ} \mathrm{C}$ thereafter. The tubers were evaluated 3 months after harvesting for powdery scab infection on tubers and PMTV-induced tuber necrosis. The total number of tubers examined was 416 in the first trial and 546 in the second. PMTV incidence and severity index were determined using previously published protocols (Nielsen and Molgaard 1997). Washed tubers were cut lengthwise into 1-cm-thick slices with a SafeHands Professional Mandolin slicer (Jaccard Corporation). PMTV incidence was calculated as the number of tubers showing symptoms of PMTV-induced tuber necrosis per the total number of tubers examined for each sample. The number of slices per tuber with internal necrosis $(a)$ was determined. The tuber slice with the most severe internal necrosis was covered with a clear transparency with 1-cm-wide vertical and horizontal strips, creating a grid of $1-\mathrm{cm}$ squares. The number of squares with necrosis $(b)$ was recorded. An index of PMTV severity was calculated by multiplying the two measurements $(a \times b)$ and expressing the values between 0 and 1 , where 0 indicates no necrosis and 1 indicates the presence of necrosis throughout the tuber.

Powdery scab on tubers was visually assessed and severity scored by comparing the area of tuber covered by disease with a modified graphic scale (Falloon et al. 1995). An average percentage of the sample disease severity was calculated from the total number of tubers produced in each experimental unit. Powdery scab symptoms were confirmed by observation of cystosori under the microscope $(\times 400)$ when required. Incidence was obtained by calculating the percentage of symptomatic tubers from the total number of tubers in the sample.

Confirmation of PMTV by reverse-transcription polymerase chain reaction. Necrotic tissues were taken from slices of potato tubers with a sterilized scalpel. The tissues were crushed in liquid nitrogen and stored at $-80^{\circ} \mathrm{C}$ until used for RNA extraction. Total RNA was extracted using TRIzol reagent (Life Technologies) according to the manufacturer's instructions, with the exception that $0.8 \mathrm{ml}$ was added to each tube for tissue homogenization instead of $1 \mathrm{ml}$. The RNA pellets were air dried for 5 to $10 \mathrm{~min}$ and, thereafter, the pellets were dissolved in $100 \mu$ l of RNasefree water. Detection of PMTV in tubers was done by reversetranscription polymerase chain reaction (RT-PCR) according to a previously published protocol (Nakayama et al. 2010), with the only modification being the use of $0.2 \mu l$ of random primers $(500 \mu \mathrm{g} / \mathrm{ml})$ and $3.3 \mu \mathrm{l}$ of RNase-free water instead of 1 and $2.5 \mu \mathrm{l}$, respectively. In total, 51 and 10 symptomatic tubers of Dakota Crisp and Ivory Crisp, respectively, were tested for the presence of PMTV in the first trial. For the second trial, 35 and 13 symptomatic tubers of Dakota Crisp and Ivory Crisp, respectively, were tested. 
Statistical analysis. Statistical analyses of the experimental data were carried out using the Statistical Analysis Software (SAS), version 9.3. Combined analyses of variance (ANOVA) were carried out for the two experiments as variance homogeneity existed in all parameters investigated (Millikin and Johnson 1992). Residual plots of the data sets revealed that ANOVA could be performed without prior transformation as major assumptions were satisfied. Treatments were compared using the Fisher's protected least significance difference test at $P \leq 0.05$. The Pearson's correlation coefficient was calculated on moisture regimes summed across cultivar levels for comparisons $(n=8$, degrees of freedom $=6)$.

\section{Results}

PMTV was readily confirmed in symptomatic tubers of both cultivars by RT-PCR. The data for trials one and two were combined for all parameters before analysis and the results are presented accordingly.

S. subterranea f. sp. subterranea root gall formation. A significant interaction $(P<0.0007)$ was found between moisture regime and cultivar in $S$. subterranea $\mathrm{f}$. sp. subterranea gall formation on roots of plants. There was no significant difference among the four moisture regimes in Dakota Crisp (Fig. 1). However, in Ivory Crisp, the number of root galls formed in the WT regime was significantly higher than those formed in the other moisture regimes (Fig. 1). There was no significant difference in root gall formation between WEDL and DEWL moisture regimes but a significantly higher number of galls was formed in the WEDL regime than the DT regime. This indicates that the effect of moisture regime on the formation of root galls was cultivar dependent. The results show that Ivory Crisp is more susceptible to root gall formation than Dakota Crisp, and this difference is most evident when soil moisture content is high. There was a very strong positive correlation between root gall data for trial one and trial two $(r=0.96$, $P<0.001)$.

Powdery scab infection on tubers. The incidence $(P<0.0012)$ and severity $(P<0.0049)$ of powdery scab infection on tubers differed significantly among moisture regimes. The mean incidence of powdery scab lesions on tubers ranged from $15 \%$ in the DT moisture regime to $32 \%$ in the WT regime (Table 1). The mean powdery scab incidence in the DEWL regime was not statistically different from that of the WT regime but both regimes had

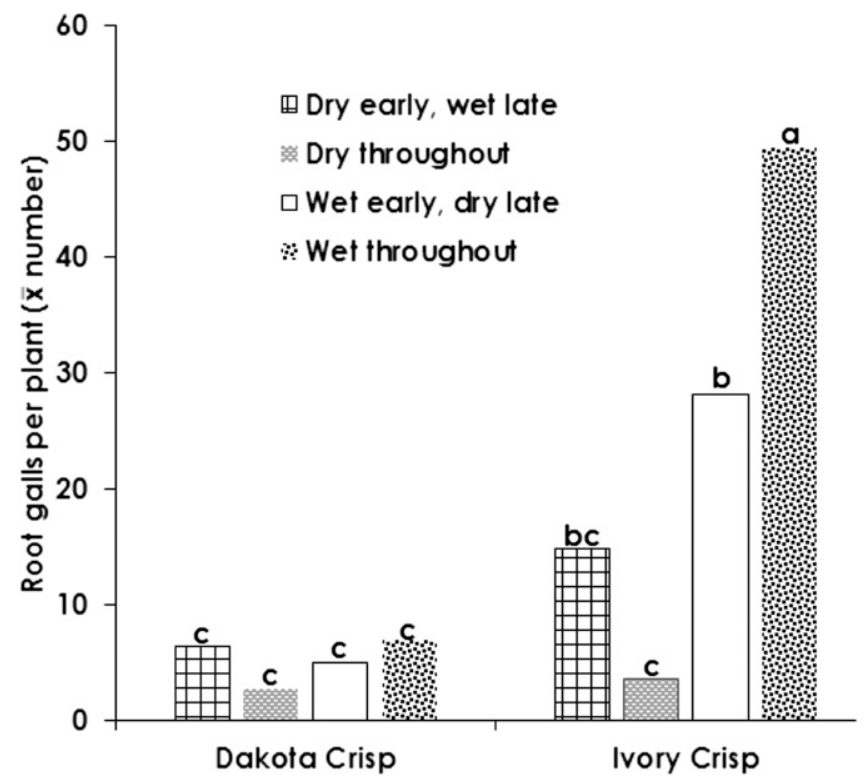

Fig. 1. Mean number of Spongospora subterranea f. sp. subterranea galls on roots across soil moisture regimes in Dakota Crisp and Ivory Crisp. Data represent the interaction between moisture regime and cultivar on root gall formation based on data combined after two trials. Means with the same letter are not significantly different based on Fisher's protected least significance difference $(P<0.05)$. significantly higher incidence than WEDL and DT regimes. The mean powdery scab severity was highest in DEWL $(0.7 \%)$ and lowest in the DT moisture regime $(0.2 \%)$ (Table 1$)$. No significant difference was found in incidence or severity of powdery scab between Ivory Crisp and Dakota Crisp. A significant $(r=0.86, P<$ 0.01 ) positive correlation was found between powdery scab incidence and severity.

Potato mop-top virus-induced tuber necrosis. PMTV tuber necrosis incidence $(P<0.0008)$ and severity $(P<0.0009)$ differed significantly among moisture regimes. The range of PMTV tuber necrosis incidence varied from $4.1 \%$ in DT regime to $18.0 \%$ in WT regime (Table 2). PMTV tuber necrosis incidence was significantly higher in WT, DEWL, and WEDL moisture regimes than that of DT regime. Significantly higher PMTV tuber necrosis incidence was found in the WT regime than WEDL regime but both of these regimes did not differ significantly from the DEWL regime in tuber necrosis incidence. PMTV tuber severity index ranged from 0.04 in the DT to 0.15 in the WT moisture regime (Table 2). The PMTV severity index did not differ statistically among the DEWL, WEDL, and DT regimes. Ivory Crisp and Dakota Crisp differed significantly in tuber necrosis incidence $(P<0.0001)$, at 5.8 and $17.0 \%$, respectively, across moisture regimes (Table 3). PMTV tuber necrosis severity also differed significantly between Ivory Crisp and Dakota Crisp across moisture regimes (0.03 and 0.14 , respectively) (Table 3). A very strong positive correlation was found between PMTV tuber necrosis incidence and severity index $(r=0.95, P<$ $0.001)$. PMTV incidence $(r=0.74, P<0.05)$ and severity $(r=$ $0.88, P<0.01)$ data for the first trial were significantly correlated with those of the second trial.

Relationship between $S$. subterranea f. sp. subterranea root galls, powdery scab, and PMTV tuber necrosis. There was no correlation between root gall formation and powdery scab on tubers. Similarly, no correlation was found between root gall formation and PMTV tuber necrosis. The correlation between PMTV tuber necrosis severity and powdery scab severity on tubers was also not significant $(r=0.42, P<0.20)$. However, a significant correlation was

Table 1. Mean powdery scab incidence and severity among four moisture regimes across two potato cultivars

\begin{tabular}{lcc}
\hline & \multicolumn{2}{c}{ Powdery scab $^{\mathbf{y}}$} \\
\cline { 2 - 3 } Moisture regime $^{\mathbf{z}}$ & Incidence (\%) & Severity (\%) $^{\text {(\%) }}$ \\
\hline WT & $31.9 \mathrm{a}$ & $0.6 \mathrm{ab}$ \\
DEWL & $28.5 \mathrm{a}$ & $0.7 \mathrm{a}$ \\
WEDL & $18.6 \mathrm{~b}$ & $0.4 \mathrm{bc}$ \\
DT & $15.3 \mathrm{~b}$ & $0.2 \mathrm{c}$ \\
LSD $_{0.05}$ & 9.32 & 0.35 \\
\hline
\end{tabular}

y Means with the same letter are not significantly different based on Fisher's protected least significance difference (LSD; $P=0.05$ ).

${ }^{\mathrm{z}} \mathrm{WT}=$ wet throughout, DEWL $=$ dry early/wet late, WEDL $=$ wet early/dry late, and DT $=$ dry throughout.

Table 2. Mean Potato mop-top virus (PMTV) tuber necrosis incidence and severity index among four moisture regimes across two potato cultivars

\begin{tabular}{lcc}
\hline & \multicolumn{2}{c}{ PMTV tuber necrosis $^{\mathbf{x}}$} \\
\cline { 2 - 3 } Moisture regime $^{\mathbf{y}}$ & Incidence (\%) $^{(18.0 \mathrm{a}}$ & Severity $_{\text {index }}^{\mathbf{z}}$ \\
\hline WT & $12.6 \mathrm{ab}$ & $0.15 \mathrm{a}$ \\
DEWL & $10.9 \mathrm{~b}$ & $0.06 \mathrm{~b}$ \\
WEDL & $4.1 \mathrm{c}$ & $0.08 \mathrm{~b}$ \\
DT & 6.6 & $0.04 \mathrm{~b}$ \\
LSD $_{0.05}$ & 0.06 \\
\hline
\end{tabular}

${ }^{x}$ Means with the same letter are not significantly different based on Fisher's protected least significance difference (LSD; $P=0.05$ ).

y WT $=$ wet throughout, DEWL $=$ dry early/wet late, $\mathrm{WEDL}=$ wet early/dry late, and DT $=$ dry throughout.

${ }^{\mathrm{z}}$ Index is given as a value between 0 and 1 , where 0 indicates no tuber necrosis and 1 presence of necrosis through the tuber (Nielsen and Molgaard 1997). 
found between powdery scab incidence on tubers and PMTV tuber necrosis incidence $(r=0.7, P<0.05)$.

\section{Discussion}

To the best of our knowledge, this is the first report establishing the direct relationship between soil moisture regime and the development of PMTV tuber necrosis in a controlled experiment. The only previous reports linking soil moisture content and PMTV tuber necrosis were based on field observations in Europe (Carnegie et al. 2012; Cooper and Harrison 1973; Davey et al. 2008; Jones 1988).

The results of this study show that maintaining soil moisture level at $90 \%$ field capacity (wet) throughout the growing season results in high PMTV tuber necrosis incidence, while keeping moisture level at $60 \%$ field capacity (dry) leads to low tuber necrosis incidence. The results also indicate that keeping the soil dry early in the growing season and wet later and vice versa may result in a similar PMTV tuber necrosis incidence. However, the WEDL regime resulted in significantly lower tuber necrosis incidence in comparison with the WT regime. In Scotland, observations were made on more than 130 fields of seed potato in different parts of that country in 1971 and 1972 to investigate whether PMTV tuber necrosis development is influenced by wet, cool weather, as reported for S. subterranea f. sp. subterranea infection (Cooper and Harrison 1973). Results of that study showed that PMTV tuber necrosis incidence increased as potential water deficit decreased, and subsequent correlation analysis revealed that PMTV tuber necrosis was more prevalent as rainfall increased (Cooper and Harrison 1973). Virtually no PMTV tuber necrosis occurred when annual precipitation was below $760 \mathrm{~mm}$ (Cooper and Harrison 1973). Even though our experimental design differs from that study (Cooper and Harrison 1973), results of both studies are similar and imply that high soil moisture levels lead to high incidence of PMTV tuber necrosis. In another study in Denmark, the incidence of PMTV tuber necrosis was shown to correlate best with precipitation at the period when stolon formation and tuber set occurs (Jones 1988). This implies that PMTV tuber necrosis incidence would be highest when soil is wet in the first half of the season because stolon formation and tuber set mostly occur at this time. Our results suggest that high PMTV tuber necrosis incidence may occur when soil is wet late in the growing season as well. Because multiplication of $S$. subterranea $\mathrm{f}$. sp. subterranea zoosporangia occur through the season, the build-up of PMTV inoculum is expected and, with new stolons and tubers being formed even toward the end of the growing season, the high tuber necrosis incidence in the DEWL regime is not surprising. However, these results should be interpreted with caution insomuch that the first tubers were probably formed several weeks after planting and, as a result, the wet period in WEDL affecting the tubers and PMTV infection was probably much shorter than in the DEWL, which alone may explain why incidence of tuber necrosis was lower in WEDL than DEWL regimes.

Unlike PMTV tuber necrosis, the effect of soil moisture regime on S. subterranea f. sp. subterranea infection has been extensively studied (Adams et al. 1987; Burnett 1991; Diriwächter and Parbery 1991; Hughes 1980; Nachmias and Krikun 1988; Taylor and Flett 1981; Taylor et al. 1986; Van De Graaf et al. 2005, 2007). In our study, root gall formation was significantly greater in plants grown in soil kept wet throughout the growing season than those subjected to fluctuating wet and dry regimes. A similar outcome was found with the incidence of powdery scab on tubers; however, the difference between the WT and DEWL regimes was not significant. In a similar study, plants grown in constant dampness had greater tuber and root gall incidence than those subjected to fluctuating regimes of wetness, though the effect on root gall formation was not significant (Van De Graaf et al. 2007). There are contrasting reports about the importance of constant versus fluctuating soil moisture conditions in powdery scab development. While some authors found powdery scab incidence and severity to be significantly higher under the condition of constant dampness than fluctuating wet and dry conditions (Adams et al. 1987; Van De Graaf et al. 2005, 2007), others concluded that fluctuating conditions are more conducive (Burnett 1991; Hims 1976a). Under conditions of constant high soil moisture, oxygen levels may be depleted while carbon dioxide levels increase, which has been reported to slow down tuber development and prolong the period of susceptibility to infection by $S$. subterranea f. sp. subterranea, thereby favoring disease development (Diriwächter and Parbery 1991).

In the current study, powdery scab incidence and severity were significantly higher in DEWL than WEDL moisture regimes. Our finding supports the work of researchers who found that powdery scab infection may result from wet conditions later in the growing season (Adams 1975; Christ and Weidner 1988; Diriwächter and Parbery 1991; Forsund 1971; Hims 1976a,b; Parker 1984). High levels of powdery scab infection have been reported to occur if soil is maintained at field capacity for 20 to 40 days, having been dry prior to tuber initiation (Hims 1976a). In Australia, it was reported that, for two consecutive seasons of field trials, delaying irrigation until tuber set did not decrease powdery scab severity (Taylor et al. 1986). Uneven tuber set, which was evident at the time our experiment was harvested, coupled with the proliferation of lenticels on mature tubers by high moisture levels later in the season, ensured that tubers remained susceptible for a longer period and may partially explain our results. On the other hand, due to the possibility of tubers forming weeks after planting, the period of time during which tubers were exposed to wet conditions in the WEDL may have been much shorter than in the DEWL, and this may explain why powdery scab infection was higher in DEWL than WEDL moisture regimes.

In the study reported here, no correlation was found between the occurrence of galls on roots and powdery scab on tubers (Christ 2001; Van De Graaf et al. 2007), or between root gall formation and PMTV tuber necrosis. Our results also show that Ivory Crisp is susceptible to root galling but tolerant to PMTV tuber necrosis, while the direct opposite is true for Dakota Crisp. Our results partially agree with the findings of field investigations in which Ivory Crisp was found to be moderately susceptible to root galling while Dakota Crisp was shown to be moderately resistant (F. G. Bittara, personal communication) and further support the lack of correlation between root galling and PMTV tuber necrosis. The correlation found between powdery scab incidence on tubers and PMTV tuber necrosis incidence in this study is inconsistent with many published reports (Cooper et al. 1976; Kirk 2008; Montero-Astúa et al. 2008; Nielsen and Nicolaisen 2000; Sandgren et al. 2002; Tenorio et al. 2006). However, results of this growth chamber experiment are consistent with at least two other reports (Davey et al. 2014; Domfeh et al. 2015). In a study conducted in Scotland to investigate the transmission of PMTV from infected seed tubers to daughter plants, statistically significant correlations $(r=0.48$ and 0.61 in 2004 and 2005 , respectively) were found between the incidence of PMTV tuber necrosis and powdery scab formation on tubers (Davey et al. 2014). In another study, a strong overall positive correlation $(r=$ $0.62, P=0.02$ ) was found between incidence of powdery scab on tubers and PMTV tuber necrosis incidence (Domfeh et al. 2015). In that report, it was hypothesized that the correlation between powdery scab incidence and PMTV tuber necrosis incidence could be

Table 3. Mean Potato mop-top virus (PMTV) tuber necrosis incidence and severity index of two potato cultivars across all moisture regimes

\begin{tabular}{lcc}
\hline & \multicolumn{2}{c}{ PMTV tuber necrosis $^{\mathbf{y}}$} \\
\cline { 2 - 3 } Cultivar & Incidence (\%) & Severity index $^{\mathbf{z}}$ \\
\hline Dakota Crisp & $17.0 \mathrm{a}$ & $0.14 \mathrm{a}$ \\
Ivory Crisp & $5.8 \mathrm{~b}$ & $0.03 \mathrm{~b}$ \\
LSD $_{0.05}$ & 4.7 & 0.04 \\
\hline
\end{tabular}

y Means with the same letter are not significantly different based on Fisher's protected least significance difference (LSD) $(P=0.05)$.

${ }^{\mathrm{z}}$ Index is given as a value between 0 and 1 , where 0 indicates no tuber necrosis and 1 presence of necrosis through the tuber (Nielsen and Molgaard, 1997). 
due to the fact that $50 \%$ of the cultivars used in that trial were russetskinned which are tolerant to both diseases and, hence, the correlation may have been an artifact created by choice of cultivars. However, results presented in the current study, and those reported elsewhere (Davey et al. 2014), suggest that the correlation may have been real. These results suggest that $S$. subterranea $\mathrm{f}$. sp. subterranea infection of potato tubers, which may lead to the direct injection of PMTV into the tubers, has a greater chance of inducing tuber necrosis than infection via roots (Domfeh et al. 2015).

The results of this study show that soil moisture plays a significant role in the development of PMTV tuber necrosis and that an appropriate use of irrigation may reduce disease pressure. However, moisture management may play a more significant role in reducing PMTV-induced tuber necrosis in a highly sensitive potato cultivar such as Dakota Crisp than in a tolerant cultivar such as Ivory Crisp. The relationship between cultivar susceptibility and irrigation management needs to be evaluated over a much greater range of genotypes representing all market classes of potato. Further field studies are necessary to determine the merits of using irrigation management to mitigate PMTV tuber necrosis while also maintaining tuber quantity and quality.

\section{Literature Cited}

Adams, M. J. 1975. Potato tuber lenticels: Development and structure. Ann. Appl. Biol. 79:265-273.

Adams, M. J., Read, P. J., Lapwood, D. H., Cayley, G. R., and Hide, G. A. 1987. The effect of irrigation on powdery scab and other tuber diseases of potatoes. Ann. Appl. Biol. 110:287-294.

Andersen, B. A. B., Nicolaisen, M., and Nielsen, S. L. 2002. Alternative hosts for Potato mop-top virus, genus Pomovirus and its Spongospora subterranea $\mathrm{f}$. $\mathrm{sp}$. subterranea. Potato Res. 45:37-43.

Arif, M., Torrance, L., and Reavy, B. 1995. Acquisition and transmission of Potato mop-top furovirus by a culture of Spongospora subterranea derived from a single cystosorus. Ann. Appl. Biol. 126:493-503.

Burnett, F. 1991. The Biology and Control of Powdery Scab (Spongospora subterranea) of potatoes. Doctoral dissertation, University of Aberdeen, UK.

Calvert, E. L. 1968. The reaction of potato varieties to Potato mop-top virus. Rec. Agric. Res. Minist. Agric. North. Irel. 17:31-40.

Calvert, E. L., and Harrison, B. D. 1966. Potato mop-top, a soil borne virus. Plant Pathol. 15:134-139.

Carnegie, S. F., Davey, T., and Saddler, G. S. 2012. Prevalence and distribution of Potato mop-top virus in Scotland. Plant Pathol. 61:623-631.

Cassel, D. K., and Nielsen, D. R. 1999. Field capacity and available water capacity. Pages 901-926 in: Methods of Soil Analysis, Part 1: Physical and Mineralogical Methods, 2nd ed. A. Klute, ed. ASA and SSSA, Madison, WI.

Christ, B. J. 2001. Powdery scab: An emerging disease on potato. Am. J. Potato Res. 78:447-448.

Christ, B. J., and Weidner, R. J. 1988. Incidence and severity of powdery scab on potatoes in Pennsylvania. Am. Potato J. 65:583-588.

Cooper, J. I., and Harrison, B. D. 1973. Distribution of Potato mop-top virus in Scotland in relation to soil and climate. Plant Pathol. 22:73-78.

Cooper, J. I., Jones, R. A. C., and Harrison, B. D. 1976. Field and glasshouse experiments on the control of Potato mop-top virus. Ann. Appl. Biol. 83: 215-230.

Davey, T., Browning, I., Carnegie, S. F., Mitchell, W. J., and Saddler, G. S. 2008. Soil: The principal source of Potato mop top virus (PMTV) infection. Pages 205-210 in: Proc. Crop Prot. North. Britain.

Davey, T., Carnegie, S. F., Saddler, G. S., and Mitchell, W. J. 2014. The importance of the infected seed tuber and soil inoculum in transmitting Potato mop-top virus to potato plants. Plant Pathol. 63:88-97.

de Boer, R. F., Taylor, P. A., Flett, S. P., and Merriman, P. R. 1985. Effect of soil temperature, moisture and timing of irrigation on powdery scab (Spongospora subterranea) of potatoes. Pages 197-198 in: Ecology and Management of SoilBorne Plant Pathogens. C. A. Parker, K. J. Moore, P. T. W. Wong, A. D. Rovira, and J. F. Kollmorgen, eds. American Phytopathological Society, St. Paul, $\mathrm{MN}$

Diriwächter, G., and Parbery, D. G. 1991. Infection of potato by Spongospora subterranea. Mycol. Res. 95:762-764.

Domfeh, O., Bittara, F. G., and Gudmestad, N. C. 2015. Sensitivity of potato cultivars to Potato mop-top virus-induced tuber necrosis. Plant Dis. 99: 788-796.

Falloon, R. E., Viljanen-Rollinson, L. H., Coles, G. D., and Poff, J. D. 1995. Disease severity keys for powdery and downy mildews of pea, and powdery scab of potato. N. Z. J. Crop Hortic. Sci. 23:31-37.

Forsund, E. 1971. Streptomyces scabies and Spongospora subterranea observed on potatoes grown in different types of soil irrigated at different levels and times. Potato Res. 14:334-335.

Harrison, B. D., and Jones, R. A. C. 1970. Host range and properties of Potato mop-top virus. Ann. Appl. Biol. 65:393-402.
Harrison, J. G., Searle, R. J., and Williams, N. A. 1997. Powdery scab disease of potato-A review. Plant Pathol. 46:1-25.

Hernandez Maldonado, M. L., Falloon, R. E., Butler, R. C., Conner, A. J., and Bulman, S. R. 2013. Spongospora subterranea root infection assessed in two potato cultivars differing in susceptibility to tuber powdery scab. Plant Pathol. 62:1089-1096.

Hims, M. 1976a. The biology of Spongospora subterranea (Wallr.) Lagerh. f. sp. subterranea Tomlinson, the cause of powdery scab disease of potato. Doctoral dissertation, University of Leeds, UK.

Hims, M. 1976b. The weather relationships of powdery scab disease of potatoes. Ann. Appl. Biol. 84:274-275.

Hims, M. J., and Preece, T. F. 1975. Spongospora subterranea f. sp. subterranea CMI Descriptions of Pathogenic Fungi and Bacteria No. 477, page 2 Commonwealth Mycological Institute, Association of Applied Biologists, Kew, Surrey, UK.

Hughes, I. K. 1980. Powdery scab (Spongospora subterranea) of potatoes in Queensland: Occurrence, cultivar susceptibility, time of infection, effect of soil pH, chemical control and temperature relations. Aust. J. Exp. Agric. Anim. Husb. 20:625-632.

Jeffries, C. J. 1998. FAO/IPGRI Technical Guidelines for the Safe Movement of Germplasm: Potato. No. 19. Food and Agriculture Organization of the United Nations and International Plant Genetic Resources Institute, Rome.

Jones, R. A. C. 1988. Epidemiology and control of Potato mop-top virus. Pages 255-270 in: Developments in Applied Biology II. Viruses with Fungal Vectors. J. I. Cooper and M. J. C. Asher, eds. Association of Applied Biologists, Wellesbourne, UK.

Jones, R. A. C., and Harrison, B. D. 1969. The behavior of Potato mop-top virus in soil, and evidence for its transmission by Spongospora subterranea (Wallr.) Lagerh. Ann. Appl. Biol. 63:1-17.

Jones, R. A. C., and Harrison, B. D. 1972. Ecological studies on potato mop-top virus in Scotland. Ann. Appl. Biol. 71:47-57.

Kirk, H. G. 2008. Mop-top virus, relationship to its vector. Am. J. Potato Res. 85: 261-265.

Kurppa, A. 1989. Reaction of potato cultivars to primary and secondary infection by Potato mop-top furovirus and strategies for virus detection. EPPO Bull. 19: 593-598.

Latvala-Kilby, S., Aura, J. M., Pupola, N., Hannukkala, A., and Valkonen, J. P. T. 2009. Detection of Potato mop-top virus in potato tubers and sprouts: Combinations of RNA2 and RNA3 variants and incidence of symptomless infections. Phytopathology 99:519-531.

Millikin, G. A., and Johnson, D. E. 1992. One-way treatment structure in a completely randomized design with heterogeneous errors. Pages 16-28 in: Analysis of Messy Data. Vol. 1: Designed Experiments. Chapman and Hall, London.

Montero-Astúa, M., Vasquéz, V., Turecheck, W. W., Mertz, U., and Rivera, C. 2008. Incidence, distribution, and association of Spongospora subterranea and Potato mop-top virus in Costa Rica. Plant Dis. 92:1171-1176.

Nachmias, A., and Krikun, J. 1988. Etiology and control of powdery scab of potato in a semi-arid region of Israel. Phytoparasitica 16:33-38.

Nakayama, T., Maoka, T., Hataya, T., Shimizu, M., Fuwa, H., Tsuda, S., and Mori, M. 2010. Diagnosis of Potato mop-top virus in soil using bait plant bioassay and PCR-microplate hybridization. Am. J. Potato Res. 87:218-225.

Nielsen, S. L., and Molgaard, J. P. 1997. Incidence, appearance and development of Potato mop-top furovirus-induced spraing in potato cultivars and the influence on yield, distribution in Denmark and detection of the virus in tubers by ELISA. Potato Res. 40:101-110.

Nielsen, S. L., and Nicolaisen, M. 2000. National potato production and the powdery scab situation in Denmark. Pages 67-71 in: Proc. First Eur. Powdery Scab Workshop, Aberdeen, Scotland. U. Merz and A. K. Lees, eds.

Parker, A. 1984. Cultural control of powdery scab of potatoes. Pages 132-137 in Proc. Crop Prot. North. Britain. Society for Crop Protection in Northern Britain, Dundee, UK.

Pringle, C. R. 1999. Virus taxonomy-1999. Arch. Virol. 144:421-429.

Qu, X., Kavanagh, J. A., Egan, D., and Christ, B. J. 2006. Detection and quantification of Spongospora subterranea $\mathrm{f}$. sp. subterranea by PCR in host tissue and naturally infested soils. Am. J. Potato Res. 83:21-30.

Reynolds, S. G. 1970. The gravimetric method of soil moisture determination, part I. A study of equipment, and methodological problems. J. Hydrol. 11:258-273.

Salazar, L. F., and Jones, R. A. C. 1975. Some studies on the distribution of Potato mop-top virus in Peru. Am. Potato J. 52:143-150.

Sandgren, M. 1995. Potato mop-top virus (PMTV): Distribution in Sweden, development of symptoms during storage and cultivar trials in field and glasshouse. Potato Res. 38:379-389.

Sandgren, M., Plaisted, R. L., Watanabe, K. N., Olsson, S., and Valkonen, J. P. T. 2002. Evaluation of some North and South American potato breeding lines for resistance to Potato mop-top virus in Sweden. Am. J. Potato Res. 79:205-210

Santala, J., Samuilova, O., Hannukkala, A., Latvala, S., Kortemaa, H., Beuch, U., Kvarnheden, A., Persson, P., Topp, K., Ørstad, K., Spetz, C., Nielsen, S. L., Kirk, H. G., Budziszewska, M., Wieczorek, P., Obrepalska-Steplowska, A., Pospieszny, H., Kryszczuk, A., Sztangret Wisniewska, J., Yin, Z., Chrzanowska, M., Zimnoch-Guzowska, E., Jackeviciene, E., Taluntyte, L., Pupola, N., Mihailova, J., Lielmane, I., Jarvekulg, L., Kotkas, K., Rogozina, E., Sozonov, A., Tikhonovich, I., Horn, P., Broer, I., Kuusiene, S., Staniulis, J. 
Uth, J. G., Adam, G., and Valkonen, J. P. T. 2010. Detection, distribution and control of Potato mop-top virus, a soil-borne virus, in northern Europe. Ann. Appl. Biol. 157:163-178.

Taylor, P. A., and Flett, S. P. 1981. Effect of irrigation on powdery scab of potatoes. Australas. Plant Pathol. 10:55-56.

Taylor, P. A., Flett, S. P., de Boer, R. F., and Marshall, D. 1986. Effects of irrigation regimes on powdery scab disease and yield of potatoes. Aust. J. Exp. Agric. 26:745-750.

Tenorio, J., Franco, Y., Chuquillanqui, C., Owens, R. A., and Salazar, L. F. 2006. Reaction of potato varieties to Potato mop-top virus infection in the Andes. Am. J. Potato Res. 83:423-431.
Torrance, L., and Mayo, M. A. 1997. Proposed re-classification of furoviruses. Arch. Virol. 142:435-439.

Van De Graaf, P., Lees, A. K., Wale, S. J., and Duncan, J. M. 2005. Effect of soil inoculum level and environmental factors on potato powdery scab caused by Spongospora subterranea. Plant Pathol. 54:22-28.

Van De Graaf, P., Wale, S. J., and Lees, A. K. 2007. Factors affecting the incidence and severity of Spongospora subterranea infection and galling in potato roots. Plant Pathol. 56:1005-1013.

Wale, S. J. 2000. Summary of the session on national potato production and the powdery scab situation. Pages 3-9 in: Proc. First Eur. Powdery Scab Workshop, Aberdeen, Scotland. U. Merz and A. K. Lees, eds. 